\title{
The Difference between Albanian and Italian Tax Systems and the Challenges of Albanian Tax System Against the Advantages of Italian Tax System. The Investment Climate in Albania for Italian Businesses
}

\author{
$\mathrm{PhD}$ Candidate, Jonada Mamo \\ Lecturer, "Aleksandër Moisiu" University, \\ Faculty of Business, Durrës, Albania \\ Tel: +355 (0) 694423 840; e-mail: jonada.mamo@yahoo.com \\ Msc. Ina shehu \\ Student ,"Aleksandër Moisiu" University, \\ Faculty of Business, Durrës, Albania \\ Tel: +355 (0) 695677 091; e-mail: inashehu@hotmail.it
}

\section{Doi:10.5901/mjss.2013.v4n10p653}

\section{Abstract}

Every entity aims at gaining profit. Problems start when the state with its procedures prevents the realization of this aim. This paper will be based on a comparison between our two different tax systems, between Italy and Albania and for the problems that they face. During the paper will be presented the advantages of Italian tax system and the challenges of Albanian tax system, the problems with the overpaid income tax during the year; with the depreciation methods and rates; and with costs not recognized by the tax system. Also the presentation of financial statements examples for both countries. The paper is based on secondary sources in a recently study conducted by the German Association of Industry and Commerce in Albania, April 2013. In many other studies related with the tax system in Albania and based on the interpretation of IAS 16 and the recognition of depreciation as an expense in the statement of income and expenses. I have not used any econometric model to prove any hypotheses because it is more a paper to present and to compare the two different tax systems. In the results and conclusions we will see also the present situation of the Italian investment and the addition of Italian firms operating in Albania and the problems they face.

Keywords: Financial statements, tax systems, IAS 16, depreciation, income, expenses.

\section{Introduction}

Sufficient tax revenues are needed to guarantee democracy, public order and the functioning of the legal system. Modern tax should be more than just a source of revenue for government operations, taxation should also ensure that public authorities contribute actively to pursue the goals of economic policy, social and environmental. A proper road network, an efficient public transport system, a modern health service hospital providing a convenient system of education policy, environmental protection and active employment and vocational training require the injection of large doses of public finances.

Also, the tax is an important springboard for a redistribution of income among citizens. Ensuring solidarity and social cohesion in society requires large social transfers and tax needs to play an important role. Further, the tax is a tool to influence people's behavior, for example in the environmental field or in connection with active aging (reward at work). Tax policy instruments should not be competition for governments to attract investment. Policies of this kind lead to tax competition and harm the basic goals of tax policy.

The purpose of this paper is not to compare the economies of the two countries because we know that Albania and Italy have completely different economic developments. The aim is to present the real situation in these two countries and some specifics of Italian tax system that we can see as advantages of the fiscal system and fiscal policies of Italy, as a good example for our tax system. ${ }^{1}$

\footnotetext{
${ }^{1}$ Hutsebaut, M. "Tax policy according to Europian point of view"
} 


\section{The present situation of economic and politik level of the businesses in Albania and in Italy}

German Association of Industry and Commerce in Albania (DIHA) conducted a survey in cooperation with the German Chambers of Foreign Trade (AHK) in the region of Central and Eastern Europe, in the period 01 February to 03 March 2013. The results of this survey assessed the economic situation in Albania negatively! $64 \%$ of respondents assess the economic situation in Albania as negative, this assessment in 2012 had only 36\%. Forecasting the future for 2013 estimated by $52 \%$ of respondents as "bad". The study showed that Albania has a lower than CEE average, as in previous years, the survey results, this year are quite critical in terms of the economic climate in Albania.

The most critical estimates in this survey were for the factors of doing business, which are very important elements of decision making when businesses decide where to invest. The results of the evaluation on personal business situation in the respective companies continue to become worse. In $2011,67 \%$ of respondents assess their business situation as "good", in 2012 this figure dropped to 42\%, and in 2013 only 24\% still had this assessment. Economic situation and especially the political situation in Albania are evaluated negatively. 55\% of respondents say how much disappointed they are with the fight against corruption and criminality. Dissatisfied with public administration in Albania are $52 \%$ of respondents, while $48 \%$ are dissatisfied with the predictability of economic policies. $^{2}$

\section{The main changes in the Italian tax area are listed below:}

It was brought forward to 2012 the possibility for regions to ordinary statute to increase or decrease the rate of personal income tax base $(0.9 \%)$, however, limits are the additional amount which must be contained within the limits of $0.5 \%$ for $2012-2013$, at $1.1 \%$ for 2014 and 2.1\% from 2015. It has been also suspended the powers of the regions and local authorities to resolve to increase the taxes, surtaxes, the rates and surcharges (except for the municipal surtax starting in 2012) to the definition of the new Stability Pact of procedure.

Establishment of a solidarity contribution. It was introduced a solidarity contribution for the years 2011 - 2012 - 2013 of $5 \%$ on total income exceeding $€ 90,000$ per year and $10 \%$ higher than $€ 150,000$, this contribution is deductible from the total income; ${ }^{3}$

Reduction of exemption schemes, exclusion and favorable tax of 5\% for 2012 and $20 \%$ by 2013 ;

Standards on combating money laundering and the relative reduction in the use of cash for amounts less than $€$ 2,500 ;

New rules on the taxation of financial income. Will be applied to parts of a single rate 20\% from 1 January 2012 on tax on capital gains realized replacement of non-qualified investments on equity instruments and contracts of association in participation with capital injection, titles (excluding securities issued by public agencies and state and Titles white list of countries and savings bonds for the southern economy for which the tax remains at $12.5 \%$ ), certificates of mass, currencies sold to term or arising from deposits, precious metals and shares in investment undertakings. The single rate of $20 \%$ also applies with regard to the withholding tax on interest on bonds, promissory notes and similar securities, the withholding tax on dividends from non-qualified investments, listed and unlisted companies and the bank interest. The taxation of financial income to $20 \%$ is then went to replace the pre-existing split into two different tax rates of $27 \%$ for the interests of the deposits, bank accounts, and $12.5 \%$ for all other financial income. With regard to capital losses until 2011 on financial instruments mentioned above is expected from future capital gains deduction limited to $62.5 \%$ instead of $100 \%$;

Finally, the law no. 183/2011 (Stability Law for 2012) has provided some news about the following aspects:

Guarantor of the taxpayer. It has been changed the structure of the organ from collegiate to tribunal and has been introduced new causes of incompatibility from office

Free of tax productivity bonuses for the years 2012 - 2014 through the application of a "substitute tax of $10 \%$ on salaries paid to private employees related to increases in productivity;

Remission of fees relating to the apprenticeship contract; Increase in excise duties (fuel taxes) on motor fuels;

Changes to the rules of traceability for professionals and partnerships with simplified accounting;

Increase of the unified. The unified contribution has been increased by 50\% in the judgments of appeal and doubled in the proceedings before the Court of Cassation.

According to the Albanian tax legislation

\footnotetext{
2 German Association of Industry and Commerce in Albania

${ }^{3}$ Ceriani, V. Franco, D. "Audizione nell'ambito dell'indagine conoscitiva sulla riforma fiscale e assistenziale" (AC 4566), Banca d'Italia.
} 
- Are excluded from the obligation to complete and submit an annual individual statement of income all individuals that realize their annual gross income from all sources in the total amount of less than 2 million (two million).

To take advantage of deductible expenses for children and for persons in custody, provided the letters "b" and "c" of paragraph 1 of Article 13/3 of this law, part of the statement, which belongs to these costs, supplemented only the head.

- Non-residents do not benefit from the right to the calculation of deductible expenses, as provided in paragraph 1 of this Article. ${ }^{4}$

It should be noted that no Albanian families, maintain family balance to any economist. This is because economic difficulties, fiscal infrastructure, lack of economic knowledge and culture.

Natural and legal persons, entities of local tax on small business, within the meaning of Article 10 of Law no. 9632, dated 30.10.2006 "On the local tax system", with estimated annual turnover of under 2 million, must declare, under the terms defined in this section only if the annual turnover for the year exceed 2 million.

Income individuals and legal entities, subject to local tax on small business, which conducts an annual turnover not exceeding 8 million and not less than 2 million are subject to personal income tax.

The tax period begins on January 1 and ends on December 31 of each calendar year.

The applicable tax rate on taxable income of small businesses, subject to personal income tax is 10 percent.

Small and big businesses, taxable profit for the tax period is determined by the balance sheet and its annexes, which should be in accordance with the law "On Accounting and Financial Statements"

1. If taxable profit results negative in a tax period, loss may be covered by profits in the next three tax periods, according to the principle" first loss last before it".

2. If during a taxable period the direct and / or indirect capital or voting rights of a person, varies by more than 50 percent in value or in number, the preceding paragraph shall not apply to losses of the legal person in that tax period and in previous tax periods.

The tax rate on profits to 31 December 2007 was 20 percent, while from 1 January 2008 will be 10 percent.

\section{Table of tax to income from employment}

\section{From 01.05.2013}

For income from 0-30000 ALL do not pay any obligation.

For income from 30001 - more, tax rate is $10 \%$ on gross salary.

The minimum wage is 21000 ALL or EUR 150 and maximum salary is EUR 91475 or EUR 650.

According to the Italian tax legislation

\subsection{Personal income tax (PIT)}

The tax on personal income is regulated in the Consolidated Income Tax Act (the "Tax Code"). Individuals resident in Italy are subject to IRPEF income earned both in Italy and abroad. Individuals who are not resident for tax purposes in Italy are subject to IRPEF only on income earned in Italy. Taxable income is subject to taxation by the application of progressive tax rates that, at present, ranging from $23 \%$ to $43 \%$, plus a contribution of $3 \%$ for income in excess of $€$ $300,000.00(2011-2013)$.

\subsection{Taxation of individuals}

Individuals resident in Italy are subject to IRPEF for income earned both in Italy and abroad. Individuals not resident in Italy are subject to IRPEF only for income earned in Italy.

For individuals the tax period coincides with the calendar year.

\section{The tax rates}

The tax rates to apply to the total income (by five reductions) are the following:

\footnotetext{
${ }^{4}$ Low Nr. 8438, date 28.12.1998 for the tax income changed
} 
Base imponibile Aliquote

Up to 15.000 euro $23 \%$

15.001 euro - 28.000 euro $27 \%$

28.001 euro -55.000 euro $38 \%$

55.001 euro - 75.000 euro $41 \%$

Over 75.000 euro is $43 \%$.

For the tax years $2011-2013$ is provided a contribution of $3 \%$ for income in excess of $€ 300,000$ (2011-2013) to be applied to the portion of income exceeding that threshold. In particular, the gross tax is determined by applying the income tax rates to the total income, the sum of all incomes fall within the aforementioned categories, net of certain deductible expenses (eg, medical expenses, periodic payments paid to a spouse, social security contributions and assistance).

\section{Corporate income tax (IRES)}

Income tax for companies is also governed by the Tax Code. Companies resident in Italy for tax purposes are subject to this tax for income earned in Italy and abroad. Non-resident for tax purposes in Italy are subject to IRES only on income from Italian sources, when the income comes from Italian subjects. In recent years the taxation of companies has experienced a significant reform and further modifications. One of the main characteristics of the fiscal system is the reduction of the rate of income tax for companies at $27.5 \%$.

\section{Comparisons between Albanian and Italian tax systems}

Initially, it must be stressed that Italy has a progressive tax system while Albania has a flat tax system. We are not going to analyse which of the systems is the best but will see some positive aspects of the fiscal system in Italy so we can take them in consideration to apply in our country.

Albania has a flat tax system, Italy has a progressive tax system. In Albania economists build financial statements for small and medium businesses, in Italy financial statements are build for families, individuals and legal entities, small businesses and corporations.

In Albania, the income tax is fixed at $10 \%$, in Italy is progressive from $23-43 \%$.

In Albania, taxable income rate for companies is $10 \%$ while in Italy is reduced the rate of income tax to $27.5 \%$ in the company.

In Albania, the state does not reimburse never if you are at a loss, while in Italy all the families who present with loss of balance are reimbursed by the state for the fiscal year and if it comes to profit next year may be compensated.

Some problematic area in our country are:

There is no implementation of the annual income tax return. As a result of this we have no family bookkeeping, do not have knowledge of many different costs that affect the financial results of the family, we do not refund in case of exit with loss of families.

There are problems with the tax infrastructure of small and medium businesses which have trade relations with unregistered individuals to the tax authorities. For example are dairy-producing businesses. They buy milk from villagers whose do not issue bills of sale and therefore they do not credited VAT from the purchase made. This situation brought to have more VAT on sales and less VAT from purchase bills every month. So businesses pay more VAT then they should. Bringing a liquidity crisis for a long period. Also not recorded purchase invoice means an expense that is not recorded and recognized in the financial results as a results they pay tax on profit more than it belongs.

Another problem for big businesses is on the recognition of depreciation expense that affects the income tax prepayment. In case of the revaluation of assets is not permitted the depreciation of revalued amount. Also where we have used the assets more than forecasted with the straight-line basis for this part we can calculate depreciation costs but thay are not recognized by tax administration more than the rates set by the law.

As you can see in the table of annual income tax declarations, income and expenses are divided into two groups: "recognized by the exercise (accounting) and reconized by the tax authorities. The state (the low) has clearly defined depreciation rates for different groups of property, plants and equipment, for example for buildings the rate is $5 \%$, for intangible asssets is $15 \%$, for machinery and equipment $20 \%$, for softewere $25 \%$, etc. If you look carefully problem lies in the recognition of the costs because if we want to depreciate a property with a higher rate than that defined by the low we will have two amount of expenses as a result, two different results on profit, one according the exercise result and 
one according to tax authorities rates of recognition. Due to this we have higher overpaid tax profit in advance. Regardless of how much is the result of exercise for the income tax is taken into account only the profit recognized by tax authorities. As we see, those criteria for some reasons are limiting factors for the development of the businesses that will treat as advantages then to the accelerated depreciation. Also on the table of income tax declaration, we can carefully notice something else. At the end of the table, respective company taken as example has 694657 ALL income tax overpaid from prior periods (on the debit side of the balance sheet) and despite this, tax authorities has assigned a monthly income tax of $30000 \mathrm{ALL}$ in advance payment. But due to a very small profit even this year it increase the amount of creditable tax overpaid and to finish this credit account takes time. In other words the government takes businesses' money, fills the state crates, use them and then turns them back when he want the same thing like the creditable account of the value added tax. In a time where all that overpayment of 877427 ALL may be able liquidity in the firm to improve the business charges against suppliers, or it might be too invested at an interest rate of $\mathrm{x} \%$ for all block holding period from tax administration. ${ }^{5}$

\section{Figure 1.}

\begin{tabular}{|c|c|c|}
\hline Te ardhurat dhe shpenzimet & Te ushtrimit & Tatimere \\
\hline (8/9) Te ardhurat & 4321.041 .00 & $4,321081,00$ \\
\hline$(10 / 11)$ shpenzimet & 3748741,00 & $3.748 .741,00$ \\
\hline (12) Shpenaimet c pasbritshue & & 0,00 \\
\hline \multicolumn{3}{|l|}{ Recultati } \\
\hline \multicolumn{3}{|l|}{$(19 / 14)$ Ifumbja } \\
\hline (15/16) Vitimi & 572300.00 & 572.300 .00 \\
\hline (17) Humbje e mbartur & & 0.00 \\
\hline (18) Fitimi i tatuestets nete (16-17) & & 572.300 .00 \\
\hline \multicolumn{3}{|c|}{ Llogaritja e tatim firimit } \\
\hline (5) Tatim fitimi me shkallen tatimare standarte & & $57.230,00$ \\
\hline (20) Tatim ntimi me perqindje te tjera & & 0.00 \\
\hline (21) Tatim fitimi $(19+20)$ & & $57.230,00$ \\
\hline (22) Tatim fitimitishtyre & 0,00 & \\
\hline (23) Parapagime & $240.000,00$ & \\
\hline (24) Kredi e mbartar nes periudha e meparshme & $694.657,00$ & \\
\hline (25) Kerkese per rimbursim & 0,00 & \\
\hline (26) Tation fitimi i mbipaguar & $877.427,00$ & \\
\hline \multicolumn{3}{|l|}{ (27) Tatim fimini detyrueshem per tu paguar } \\
\hline (25) Denime / interesa per vanesa & & 0,00 \\
\hline (29) TOTALI PER TU PAGUAR & & 0.00 \\
\hline
\end{tabular}

\section{Deductible expenses under Italian tax legislation}

According to Italian tax legislation you are entitled to a benefit of $19 \%$ discount for medical expenses, passive interest on house loans for the money to repair buildings and even though they are different from the first house (signed in 1997), passive interest on loans ranging from 1998 for the construction or reconstruction of first houses, passive interest for agricultural loans and debts, funeral expenses, school fees and other expenses.

\subsection{Medical expenses}

For medical expenses, of any type (medical / general, specialist, surgical, pharmaceutical, etc..) have the right to have a tax deduction of $19 \%$ after having subtracted the amount of EUR 129.11. Should gather all the expenses incurred and subtract EUR 129.11, the discount up to 19\% will be held value. If the expenses incurred during the year do not over the sum of EUR 129.11 you have no rights to any deduction.

\footnotetext{
${ }^{5}$ Mamo, J."The importance of measurement, recognition and presentation of a group of expenses that although secondary expenses, play an important role in the entity's financial result" 2013.
} 


\subsection{Passive interest on loans}

The law here is a little tricky. The deduction is applied to the interest that you must pay on bank. You are entitled to this deduction only when it is the first house purchase and the maximum value of the interest on the loan should not be considered superior to EUR 3615.20 therefore can not be reduced more then to EUR 686.89, equal to $19 \%$ of 3615.20 euros.

\subsection{Expenditure on education}

Expenses that have to pay to attend courses for secondary schools providing instruction or university can receive a 19\% discount of the value spent.

\subsection{Discounts for first home}

If you are the owner of the apartment where you live, you are eligible for a discount versus income tax increased by $5 \%$. If you make the regulation of roofs or entrances, the state returns back to you $50 \%$ of the value in 10 years by not paying taxes. If you are a tenant of a house used as a main residence, and your earnings are lower overall than Euro 30,987.41 may have facilitated (discount), which should be note in the income statement. If the contract is in the name of your spouse you have $50 \%$ discount for each part.

\subsection{Pension contributions or assistance}

If you are an employee or an independent entrepreneur, you have to pay contributions predictive and aid provided by law to guarantee pension. If you are the employer must pay employee wages and should pour to the State predictive and welfare contributions belonging. When completes the statement can remove from your income as an entrepreneur or as an independent employee the sum poured for these contributions figure for these contributions have shed. If you have a household employee, you can deduct from comprehensive income, payments made to a limit, a maximum of EUR 1549.37 .

\section{The present situation of Italian businesses in Albania}

Many foreigners, Italian businessman, who come with a great desire to do business in Albania, come with the idea that will find many fiscal facilities to spread their business. Actually in Albania the labor is very cheap and there is so much more taxes in Italy. Therefore, they come and perform in Albania part of the labor and export back to the place where it will be sold, in Italy. They are just having important fiscal policy, strategy and management of taxes in the country. Actually, they face many problems related to the corruption, Albanian culture, employee's culture and language, tax administration employees etc. We have made progress but we still have more work to do.

\section{Recommendation and conclusion}

Tax infrastructure should take into consideration to make possible disclosure of personal income and maintaining a family balance sheet. Issued receipts for every service that is paid by the head, which certify payments and documents used as justification for the eligibility of expenditure during construction period.

Tax adequate infrastructure to help the management of small businesses and manufacturing businesses, as a country that is more productive than industrial. We can help local manufacturers to increase welfare more then to import products from abroad at a lower price and quality.

Regarding income tax which is prepaid, hope to change this procedure and firms may pay taxes after reporting sales and purchases and not to prepay an amount greater as it is usually, because it blocks liquidity, which can be used to liquidate suppliers, not to take credit, or put them in deposit placed with interest.

The comparison between the two tax systems, considers that the Italian system offers several advantages compared to our tax system, as in the case of establishing the necessary infrastructure to actual recognition of revenues and expenses and reimbursement of the family balance sheet in case of a loss. 
It also offers several facilities that we can also apply, as lower tax rate for businesses that open for the first time, for physical persons who have a talent, a skill, something that produce and sell, or offering their physical service.

On the other hand, the income tax rate for corporations is really higher when in Albania is $10 \%$ but it should be noted that Italy has an economic growth much higher than Albania. The differences are very high in taxable income from wages especially. We see that in Albania minimum wage is EUR 150 while the maximum is EUR 650, while in Italy there are other wages much higher as a result of the economic development and the conditions and standards of the European Union.

Reliability, can and should we rely on this quality characteristic of the balance sheet of our economic units. In other words, can we have full credibility that this balance sheet that is submitted to the Tax Department will be the same as the balance sheet submitted to the branch of a bank at the time of a loan application? In fact we know that there are different balance sheets in the Tax Department and different balane sheets in banks and this because the state hasn't total control in its hand and due to all the problems that the tax system has.

Despite the inherent differences between our two countries, Italian tax system provides some fiscal facilities much larger especially of the lower and middle class more than for the higher layer and for corporations by providing a higher welfare than in Albania. Italy despite undergoing crisis is an example to be taken into account because, above all, is a social state!

\section{References}

Arquilla, N. "Razionalizzato il regime fiscale dei titoli obbligazionari privati e agevolati i titoli pubblici", in Corriere tributario n. 37/2011; G. Ferranti, "I dividendi e i capital gain: tra vecchia e nuova disciplina", in Corriere tributario n. 34/2011.

Ceriani, V. Franco, D. "Audizione nell'ambito dell'indagine conoscitiva sulla riforma fiscale e assistenziale" (AC 4566), Banca d'Italia.

Christofides,N. The Gender Wage Gaps, 'Sticky Floors' and 'Glass Ceilings' of the European Union Communication from the EC to the Council (2001), Towards an internal market without tax obstacles COM (2001) 582 final. Louis University of Cyprus, University of Guelph, CESifo and IZA Discussion Paper No. 5044 July 2010.

Durante, L. "Ace: ufficiale l'aiuto alla crescita", pubblicato il 20 marzo 2012 su fiscooggi.it.

German Association of Industry and Commerce in Albania

General Directorate of Tax - Tax Legislation 2012 Law Nr. 8438, date 28.12.1998, changed.

Gialluca, A. D. "Riforma ficale: Evolzione e prospettive"

Hoti,I. "Financial Accounting, basics and intermediate", Tirane 2013.

Hutsebaut, M. "Tax policy according to Europian point of view"

Instruction Nr. 1, dated 11.01.2008 For income tax.

Low Nr. 8438, date 28.12.1998 for the tax income changed.

Low Nr. 9716 date 16.04.2007, changed.

Mamo, J."The importance of measurement, recognition and presentation of a group of expenses that although secondary expenses, play an important role in the entity's financial result" 2013.

Manestra, S. "Per una storia della tax compliance in Italia", Questioni di economia e finanza n. 81, Banca d'Italia.

Modiglian, F. "Reagan's economic policies: A critique" Oxford economic papers 40 (1988).

Università di Pavia - Luglio 2004, Dipartimento di Economia Pubblica e Territoraile. 